\title{
Hate Speech and Psychic Injury: Reflections on Nigeria's 2015 Elections
}

\author{
Chris M. A. Kwaja, Ph.D. \\ Centre for Peace and Security Studies \\ Modibbo Adama University of Technology \\ Yola, Adamawa State \\ Dr. Aishatu Yusha'u Armiya'u \\ Department of Psychiatry \\ Jos University Teaching Hospital (JUTH) \\ Jos, Nigeria
}

\begin{abstract}
In the run up to the 2015 elections, Nigeria the witnessed an alarming surge in hate speeches that were deliberately designed to inflict injuries on individuals and political parties. Through speech, broadly understood to include print and electronic media, as well as public speaking, group targeted violence were perpetrated. This paper examines the link between hate speech and psychic injury in terms of how it influenced voter behaviour and electoral outcome in the run up to the 2015 elections. The paper argues that the instrumentalisation of hate speech as a tool for the mobilisation of support for politicians and political parties, contributed significantly in sowing the seed of disharmony in a country where political affiliations and loyalty are viewed along religious and ethno-regional faultlines.
\end{abstract}

Keywords: Hate Speech, Psychic Injury, Elections, Nigeria, Violence

If all mankind minus one were of one opinion, and only one person were of the contrary opinion, mankind would be no more justified in silencing that one person than he, if he had the power, would be justified in silencing mankind. (John Stuart Mill, 1863: 35)

\section{Background}

One of the fundamental pillars of democracy is the freedom of expression, which is enshrined in the constitution. Notwithstanding this provision, there are instances whereby individuals and groups resort to hate speeches, with the intent of harming the personality of their fellow being. This occur more in politics, as people compete for power or seek to influence public policy. The notion of violence is often used interchangeably with aggression is linked to hate speech, which are perpetrated with the intent of gaining advantage or hurting another person, without necessarily involving physical injury. Whereas violence involves strong physical force against another person, this may accompany aggression but results in harming another individual.

Aggression could be verbal and results in hatred, which is an emotion rather than an idea. Crucially, the way of producing hatred is through mood and manner in which communication is transmitted, rather than the simple intellectual content (Freiman, 2013). Communication could be broken down into logical syllogism, but much of our persuasive and expressive activity takes place at the emotional level. Political expressions, may include both emotive and intellectual content, however what separates other types of political communication from hate speech is that it is pitched on an emotion, which is intrinsically dangerous.

Violence occurs at all levels of social life, and in virtually every aspect of human-life as such, it is a core part of human nature. As part of human existence, violence includes racial/religious violence, political violence, violence between the strong and weak, either communally or individually, violence within household, violence as an act of crime, violence between communities and finally perpetration of violence on mankind itself. In this context, hate speech lies in a complex nexus with freedom of expression, individual, group and minority rights, as well as the concept of liberty, equality and dignity (Gagliardone, Gal, Alves, \& Martinez, 2015). 
Hate speech is an expression that advocates incitement to harm particular targets that are being identified with certain social, political or demographic group. Hate speeches denigrates a particular individual or group based on their color, race, gender, disability, religion, ethnicity, sexual orientations and other characteristics, thereby, threaten or encourage violence. These expressions extend to foster a climate of intolerance, prejudice on the assumption that it may result in targeted violent attacks, hostility and indiscrimination. In critical periods especially during elections, hate speeches tend to be broader(Gagliardone, Gal, Alves, \& Martinez, 2015).

In Nigeria, hate speeches are often motivated by politics that is a precursor to election violence and other related harassments. According to Waldron (2012):

Don't be fooled into thinking you are welcome here. [...] You are not wanted, and you and your families will be shunned, excluded, beaten, and driven out, whenever we can get away with it. We may have to keep a low profile right now. But don't get too comfortable. [...] Be afraid (Waldron 2012).

The other type of message is to let others with similar views know they are not alone, so as to reinforce sense of an in-group that is under threat such as:

We know some of you agree that these people are not wanted here. We know that some of you feel that they are dirty (or dangerous or criminal or terrorist). Know now that you are not alone. [...] There are enough of us around to make sure these people are not welcome. There are enough of us around to draw attention to what these people are really like (Waldron 2012).

It is in he light of the foregoing that this paper seeks to examine the extent to which hate speech impacted on Nigeria's electoral process in the run to the 2015 general elections. The attitude and speeches of politicians, political parties and other actors contributed significantly in shaping the electoral process as well as determining the outcome of the elections. More so that, much of the violent confrontations that occurred in the run to the elections, were linked to one form of hate speech or the other.

\section{Hate Speech and the 2015 Elections}

In the run up to the elections, political campaigns were organized with the aim of influencing the electorate across identity or economic fault-lines, within aspecific environment. The use of hate speeches served as a too for the mobilization of individuals, groups, organizations or communities. The importance of this is to show people and in particular a political candidates ability to sensitize the political community so as to make the community consider them as potentials and better representative of the people (Lynn, 2009).

Therefore for any political campaign to be effective and efficient mobilization force to influence the decision of the people, the message contained must be attainable and convincing. Lynn (2009) opined that:... What seems to be very important in any political campaign is the ,message ${ }^{\text {ee }}$ that is sent to the electorates. A campaign message is an important and potent tool that politicians use to express views and feelings to the public with the intention of reshaping and redirecting the electorates ${ }^{\text {ee }}$ opinions to align with theirs. The message should be a simple statement that can be repeated severally throughout the campaign period to persuade the target audience or influence voters ${ }^{\text {ee }}$ act in the candidates ${ }^{\text {ee }}$ favour. The campaign message ought to contain the salient ingredients that the candidate wishes to share with the voters and these must be repeated often in order to create a lasting impression on the voters.

As argued earlier on, an essential foundation of any democratic society constitutes the freedom of expression. This includes tolerance, demand for pluralism and broadmindedness without which the democratic society has no meaning (Press Unit, 2015). The foundation of any democratic society should therefore constitute tolerance and respect for the equal dignity of all human beings. That is to say as a matter of principle, in a democratic society it may be necessary to consider or even prevent all forms of expression that spread, incite, promote or justify hatred based on tolerance (Press Unit, 2015).

The Nigeria Electoral Act 2010 contains detailed provision with respect to politically motivated hate speech. Section 95 of the Act provides:

No political campaign or slogan shall be tainted with abusive language directly or indirectly likely to injure religious, ethnic, tribal or sectional feeling. Abusive, intemperate, slanderous or base language or insinuations or innuendoes designed or likely to provoke violent reaction or emotions shall not be employed or used in political campaigns. 
With respect to sanctions for individuals or groups involved in perpetrating hate speech, Section 102 of the Electoral Act further provides that :

Any candidate, person or association who engages in campaigning or broadcasting based on religious, tribal, or sectional reason for the purpose of promoting or opposing a particular political party or the election of a particular candidate, is guilty of an offence under this Act and on conviction shall be liable to a maximum fine of N1, 000, 000 or imprisonment for twelve months or to both.

Para 10 (c) of the Guidelines for Political Rallies, issued by the Independent National Electoral Commission (INEC) also prohibits the use of hate speech and discriminatory rhetoric during campaigns. It states thus: Para 25(b) of the guidelines "provide that campaigns shall be in compliance with all extant laws, regulations and codes including the Code of conduct for political parties, as well as codes issued by media regulators like the National Broadcasting Commission and shall be based on issues as contained in the manifesto and constitution of the party.In the run up to the 2015 elections, political campaigns deviated from the normal norms following the above standards. These occurred because most political actors engage in hate speeches rather than sensitizing the political community to consider them potential or better representatives. This situation is fast making hate speech pervasive in the country's political landscape. Adibe (2015) gave an elaborate definition of hate speech thus:

Speech that employs discriminatory epithets to insult and stigmatize others on the basis of their race, ethnicity, gender, sexual orientation or other forms of group membership. It is any speech, gesture, conduct, writing or display, which could incite people to violence or prejudicial action. There are individuals and groups in this country who openly relish the freedom to rain insults and profile others by appropriating to themselves the role of ethnic and religious champions. The problem is that hate speech is often the gateway to discrimination, harassment and violence as well as a precursor to serious harmful criminal acts. It is doubtful if there will be hatemotivated violent attacks on any group without hate speech and the hatred it purveys.

The 2015 elections were turned into an arena of hate speech and campaigns that defied logic and common sense (Akubor, 2015). The two leading political parties, - All Progressive Congress (APC) and the Peoples Democratic Party (PDP) exchanged various politically motivated hate speeches about candidates (Kukah, 2015). Hence, the use of hate speech assumed a common place particularly when the two major political parties identified their major flag bearers.

In a report on monitoring hate speech between January and March 2015, the Centre for Information Technology and Development (CITAD) highlighted the following:

(i) That about $70 \%$ of the people disseminating hate speech in the Nigerian social media space use their identity and can therefore be reached in case of countering and follow up actions;

(ii) That $76 \%$ of the hate speeches in Nigerian social media space were transmitted through face book either as a post in a private page/group, a post in a public page/group or a response to a post/forum, followed by online articles and twitter respectively;

(iii) English language is the major language used for dissemination of hate and dangerous speeches with a visible content in Hausa Language in the Nigerian Social media space;

(iv) Over $65 \%$ of hate speech practitioners were males with female making a small percentage;

(v) Greater percentage of the contents posts use a coded language and had been used in the past and led to violence/harm; and

(vi) There are number of messages circulated whose circulation earlier had caused violence in the country

Namadi Sambo Nigerians vice president tried to use religious sentiment to divide the country and incite Muslims against Christians. ${ }^{1}$ He stated that "Buhari ya dauko pastor a matsayin mataimakinsa Kun san coci nawa yake dashi? Yanada coci 5000, don haka karku zabe su". (Translation - "Buhari has selected a pastor as his running mate, do you know how many churches he has? He has 5000 churches, so based on that, don't vote for them"). Peoples Democratic Party (PDP) through the vice president made it clear to the Nigerian populace that the ruling party was the most Islamic party in Nigeria, as nobody is more Muslim than himself, saying that his name Namadi was derived from Namadina which means somebody coming from Medina in Saudi Arabia. He also said he goes foe Hajj yearly at a rally in Jigawa state.

\footnotetext{
${ }^{1}$ Vice President Namadi Sambo's speech at a campaign rally in Jigawa state, $21^{\text {st }}$ January 2015. For more information visit nigeraibreakingnews.info>do-not-vote.....
} 
Peoples Democratic Party (PDP) led government was accused by All Progressive Congress (APC) of training special snipers to eliminate those opposing President Goodluck Jonathans re-election bid. A catholic reverend father Ejike Mbaka led claim of President Goodluck Jonathan and his wife Dame Patience Jonathan planning to kill him over his criticism on his re-election bid and the Federal Government. The hate speeches above were on an increase during the electioneering period of 2015 general elections in Nigeria. This resulted in a display of panic and confusion among the Nigerian people, with some moving away from areas their lived all their lives to places they considered safe. This could lead to anxiety and adjustment disorders in such individuals. During this same period, thugs and miscreants took advantage of the situation to warming up to cause havoc. This led to the emergency of several groups in preparation to protect their own when the chips are down (Akubor, 2015).

The role of the media in Nigeria during the 2015 election did not help matter, instead of playing an effective management in their reportage as a way of maintaining peace and stability, the media escalated the situation. They continued to play the role the devil's advocate, according to Akubor (2015), they became instrument of destruction in the hands of politicians. The Imo Broadcasting Corporation portrayed Jonathan as a hater of the Igbos and Gen Buhari to be a better alternative. The African Independent Corporation (AIT) and the Nigeria Television Authority (NTA) on the other hand aired damaging documentaries of Gen Buhari. All this divided the countries further into groups. The Nigerian newspapers were not left out as major headlines read thus: WAR DRUMS - Northerners flee Asaba, Southerners flee Northern part of Nigeria... (huhuonline.com), Boko Haram Supports Buhari Candidacy, Nigeria will burn if Buhari wins....Al-Qaeda wants to make Nigeria its next HQ (elombah.com), Boko Haram plans massive bombings in seven states - (PUNCH). Tension in Onitsha as Hausa residents flee city - (Punch), Kano Multiple Blasts: There's A Grand Design to Set Nigeria on Fire - Sultan (Leadership), Tension in Onitsha as Hausa residents flee city - (Punch).

Promoting hate speech through the media is dangerous because it's a form of enlightenment to the public, with a lot of people believing any information aired on television/radio or in prints to be the ultimate truth (Akubor, 2015). The representative of the Advertising Practioners council of Nigeria (APCON) Mal Ahmed Yelwa reported to receive complains from both APC and PDP concerning hate speech. He stated that his council never authorized any advertisement contrary to the Nigerian Law. The representative also said that his organization has no power to "organization" they can only fine media organizations (Centre for Information Technology and Development (CITAD), 2015). ${ }^{2}$

\section{Implication Of Hate Speech On Human Psychic}

Hate speech are especially painful and seem different from other denotatively comparable speech. This results from a particular affective tone, which adds vehemence to the conveyed insult. This is a reason why hate speech inflicts a special type of pain (psychological pain). The listener of hate speech not only learns the speaker's hatred against him/her or a group (political party), but also the speaker's dislike to be so severe that he/she or group chooses to express it in a conventionally insulting terms (Freiman, 2013). The pain of hate speech is a product of the listeners' knowledge of the views of the speaker which may differ somewhat from that conveyed using another form of expression. The pain that results is psychological which can lead to emotional distress. Hate speech may cause violation of social norm which may be viewed as disrespectful or even socially subordinating its targets. Hate speech during political campaigns could denigrate on a single individual and or group, gender, religion, which the listener could view as insult, leading to psychological pain and ultimately an emotional distress. Stress on the other hand when severe results in psychosocial problems which subsequently lead to moderate to severe mental health problem such as anxiety and depression, which affects the psychological wellbeing of such individual and or group.

Hate speech are harmful utterances which are intended to cause damage, irrespective of intent, which receivers perceive to be damaging. These could result in different types of injuries on multiple levels (personal, group or societal). The perceived psychological or emotional harm/pain experienced by an individual and or group results from communication taking place either at interpersonal or intergroup level depending on personal or salience of social identity respectively. A potential injury from hate speech is that it strips people of their dignity. Dignity comes from a Latin word dignus, meaning to have intrinsic excellence, worth or to be esteemed by others. "Dignity is the totality of those qualities that make a person valuable, esteemed or useful to someone else (Hercum, 1994: 101).

\footnotetext{
${ }^{2}$ Report of one-day stakeholders' forum on hate speech and the 2015 elections in Nigeria. Report by CITAD. Retrieved from: www.citad.org>Activity>report on 17/09/2015
} 
Hate speech can cause anxiety and distress if experienced as mistreatment by another person or group (Leets, 2002). According to Graumann (1998) "aggression itself is largely performed or enacted in words....everyday conflicts between competing and rivaling individual.....are, at least in their early stages, carried out verbally" (p. 45). Human dignity is undermined through the harm of hate speech with reasonable consequences, which may follow the same structural pattern as other traumatic events (Leets, 2002). However, while hate speech may be traumatizing to one individual, the same words may have no effects on another person and in some cases may even strengthen his or her restraint and tolerance. The Crisis Reaction Model is a coping model which describes three stages of a traumatic situation. The consequences of trauma according to this model fall into three domains: feeling (affect), thought (cognition), and action (behaviour). According to the predictable stages, the sequence includes (a) impact-disorganization, (b) recoil, and (c) re-organization. Immediately following a trauma in this case harmful hate speech, the receiver displays emotional reactions such as anger, denial, disbelief, and feelings of vulnerability, which takes hours to days. The second stage, recoil, entails emerging short term emotions such as fear to anger or conflicting reactions (self-blame to other blame). Others features commonly seen are loss of identity, self-respect and trust. The final stage is re-organization; this is long term attempt to cope and behavioural changes. During this stage the individual is able to come to terms with the traumatic effect of the hate speech through establishing a more effective defensive-vigilant behaviour, value revision and attitudes to adjust to daily life (Bard \& Sangrey, 1986).

Hate speech in the 2015 general elections likely include the following: The Katsina state governor, Ibrahim Shehu Shema in his speech urged his supporters to attack his opponents and crush them like cockroaches which he referred to his political opponents. ${ }^{3}$ Speaking in Hausa on the video, Shema said (Translation - "Don't worry about political cockroaches, cockroach even in the house is found in the toilet. And when you see a cockroach in your house, what do you do to it? Kill of course, and so hit them. I told you, anybody that touches you; I have come out to tell you, also touch him, and you should not leave. The politics we did in the past, where PDP members are attacked but now anyone that touch you, revenge it; there should not be mercy or moderation". The content of this speech is quite severe including the tone coming from an authority figure in the state is vital. Considering whom the speech came from and his stand in the context of the audience to whom the speech was directed too, could lead to apprehension, anxiety and disbelief to the receivers of such speech. The level of authority of the governor over the audience is relevant as the degree to which such audience is already primed to take their lead from the governor (inciter).

The Ekiti state governor, Peter Ayodele Fayose in the early 2015 took over the front pages of newspapers repeatedly warning Nigeria voters not to vote APC presidential candidate Mohammad Buhari. ${ }^{4}$ He insinuated that the presidential candidate is likely to die in office if elected, like the former late president Umaru Yaradua, who coincidently is from the same state with Mohammad Buhari. This hate speech was directed to an individual "death wish". This could be viewed as an insult, stereotyping people (coming from the same state), death is a traumatic experience and wishing somebody death could be more traumatic. Following the Crisis Reaction Model, a traumatized individual reacts in three stages; from the impact-disorganization stage, following a death wish the receiver could display an emotional reaction such as disbelieving that someone could wish him/her death and feelings of vulnerability which takes hours or days to resolve.

The Nation's first lady Dame Patience Jonathan, at the presidential campaign rally in Kogi state, described Gen. Buhari as unfit to be Nigerians president, calling him old and brain death. This hate speech could result in damage to the individuals dignity, that is damage the qualities that make a person valuable to someone else (Harcum, 1994). Making jokes of a person's age can result in normalizing negative aspects which is an effect of hate speech, this reinforces prejudice and it's hard to overcome (Costelloe, 2015).

Nigerian First Lady, Patience Jonathan was recorded to have urged the members of the Peoples Democratic Party (PDP) to stone anyone that promises them change at a presidential rally in Calabar. "Anybody that comes and tells you change, stone that person.

\footnotetext{
${ }^{3}$ Governor Shehu Shema of Katsina state, on video urging his members to kill their political opponents like For more on this video message visit: saharareporters.com $>2014 / 11 / 19>$ echo......

${ }^{4}$ Ayo Fayose Ekiti state governor's death wish newspaper adverts of Gen Buhari. See more from:

www.premiumtimesng.com>top-news

${ }^{5}$ Dame Patience Jonathan's speech at the Calabar presidential rally in March, 2015. Find more information on: www.dailytrust.com>sunday>politics $8^{\text {th }}$ March, 2015
}

80 
Anybody that tells you change, tell that person, carry your change and get away". Change is the slogan of the All Progressives Congress (APC). At the same campaign speech given at a rally which held on Monday, March 2, in Calabar, the capital of Cross River state, Dame Patience Jonathan is quoted as saying "Our people no dey born shildren wey dem no dey fit count. Our men no dey born shildren throway for street. We no dey like the people for that side." Thus making a derogatory statement obviously referring to the Northern parts of the country where the awful practice of child abandonment known as 'Almajiri' still occurs. Normalizing negative aspects of a hate speech reinforces stereotyping and very difficult to overcome, therefore group stereotyping creates tension between people, which can lead to a more serious situation in future (Costelloe, 2015).

A documentary was aired on a private television broadcasting house on Gen. Buhari, APC presidential candidate earlier in the year 2015. This documentary involved Gen. Buharis's immediate family including his late elderest daughter Zulai Buhari.

The hate speeches listed above were directed towards individuals and groups but the consequences of hate speech depend on people's own understanding regarding its occurrence. The potential motives are usually attributed to the hate epithets expression. People's response to the communicator of the message (respond strategies) as well as how they manage their own responses to the episode (coping strategies) are significant. The motives of hate speech speakers are attributed to various situations, in this case the Nigeria 2015 general election. Hate speech are experienced differently due to the attributed intent behind the speech: was the statement made to spread intolerant idea through the use of hate speech "Our people no dey born shildren wey dem no dey fit count and our men no dey born shildren throway for street. We no dey like the people for that side" (Dame Patience Jonathan, 2015), or was it an attempt to inform the public about issues of general interest. In general the perceived motive will likely influence how a receiver chooses to respond to the speaker.

Processing hurtful events involves talking with others to seek information, express emotions and be recognized as a victim, as such several research suggest certain personality characteristics to moderate the effect of stress (Burleson, Albrecht, \& Sarason, 1994). To keep away from the negative effects of stigmatization (APC before 2015 election), it is just natural for the APC (minority group) then to embed in supportive network (social media). Most of the hate speech during the Nigeria 2015 general election occurred in public. The communication was directed to a number of individuals in a public space which include Gen. Buhari, Bola Ahmed Tinubu, and several others.

There are evidence of psychological dynamics and actual biophysical effects associated with listening to hate speech (Epstein, 2008). A statistically significant correlation was found form a study between changes in clinical anxiety and the production of salivary cortisol in listeners of hate speech. This means that there is stressful and buildup of stress related cortisol, which is a high risk factor in numerous diseases from cardiovascular illness to a host of inflammatory-related illness (Epstein, 2008). This finding was not specific to any subjects' race/ethnicity or ideology the potential health impact seems to be a general effect on all listeners of hate speech. Therefore political hate speech is dangerous to health and to the wellbeing of those around you who are marked as different and thus the potential targets of hate speech-inspired violence (Epstein, 2008). This maybe the likely cause of postelection violence witnessed in Nigeria several time, as most hate speech are directed to the presidential candidate of APC, who is form northern Nigeria where most of the postelection violence takes place.

\section{Refrences}

Adibe, J (2012) Ethnicity, hate speech and nation-building, retrieved from http//www.elombah.com/index.php/article/ jideofor -adibe/12345/ethnicity-hate-speech-and- nationbuilding, on 6/06/2015

Akubor, E.O. (2015) Campaigns and electioneering: reflecting in the 2015 general elections in Nigeria",Paper presented at the Two-Day National Conference on "The 2015 General Elections in Nigeria: The Real Issues"; Organized by the Electoral Institute, Abuja. Venue: Electoral Institute Complex, INEC Annex, Opposite Diplomatic Zone, Central Business District, Abuja. 26th - 29th July, 2015.

Bard, M., \& Sangrey, D. (1986). The crime victim's book (2nd ed.). New York: Brunner/Mazel.

Costelloe, L. (2015). No hate speech movement Ireland. Retrieved from: www.nohatespeech.ie-effect-hatespeech....., on 17/09/2015 
Epstein, R. (2008). Biological markers reveal hate speech raises stress and anxiety level. Retrieved from: http://www.chicano.ucla.edu/research/HateSpeech.asp, on 17/19/2015

Freiman, M.J. (2013). Hate speech and the reasonable Supreme Court of Canada. Supreme Court Law Review, 63 S.C.L.R (2d).

Gagliardone, I., Gal, D., Alves, T., and Martinez, G. (2015). Countering online hate speech. UNESCO Series on internet freedom. Retrieved from: http://creativecommons.org/licenses/by-sa/3.0/igo/, on 16/09/2015

Graumann, C. (1998). Verbal discrimination: A neglected chapter in the social psychology of aggression. Journal for the Theory of Social Behavior, 28, 41-61.

Harcum, E. (1994). A psychology of freedom and dignity: The last train to survival. Westport, CT: Praeger.

Kukah H (2015), Hate Speech Social Media And The 2015 Election; Hate Speech; Social Media And The 2015 Election ... pointblanknews.com/pbn/.../hate-speech-social-media-2015-election/

Leets, L. (2002). Experiencing hate speech: perceptions and responses to Anti-Semitism and Anti-gay speech. Journal of Social Issues, 58(2), 341-361.

Lynn, S. (2009). Political campaign planning manual: A step by step guide to winning elections. Retrieved from: www.ndi. org/files/political.campaign-planning-manual_malaysia.pdf.

Press Unit. (2015). Fact sheet - Hate speech. European Court of Human Rights. 